\title{
Biodegradation of Hydrocarbons by Bacillus cereus Isolated from Indoor and Outdoor Air of Selected Hospitals in Ilorin, Kwara State, Nigeria
}

\author{
*ADETITUN, DO; TOMILAYO, RB; OGUNTOYE, MB; RAHEEM, AA \\ Department of Microbiology, Faculty of Life Sciences, University of Ilorin, P.M.B. 1515 Ilorin, Kwara State. Nigeria. \\ *Corresponding author: adetitun.do@unilorin.edu.ng; Tel: +238036910988
}

\begin{abstract}
Indoor and outdoor air of five (5) hospitals in Ilorin, Kwara state were sampled using settling plate method to isolate fifteen (15) bacteria. Bacillus cereus was the identified spore former. Biodegradation performance of Bacillus cereus on hexadecane and heptane using Mineral Salts Medium (MSM) was studied for 20 days at four days interval using the Jenway 6320D Spectrophotometer to assess the optical density. The degradation and utilization of the hydrocarbons occurred before the fourth day with readings for optical density obtained as $1.051 \mathrm{~nm}$ and $0.820 \mathrm{~nm}$ for hexadecane and heptane respectively. After day 4 , there was a sharp decline in the utilization of hydrocarbons. A second experiment was setup for optical density with heptane and decane utilization being checked daily for a period of 5days. Bacillus cereus utilized the hydrocarbons till the fourth day as the optical density dropped on the fifth day. The readings for decane obtained on day 4 and day 5 were $0.431 \mathrm{~nm}$ and $0.338 \mathrm{~nm}$ respectively. Also, there was a decline in the readings of heptane from $0.451 \mathrm{~nm}$ obtained on day 4 to $0.343 \mathrm{~nm}$ obtained on day 5. This study shows that Bacillus cereus is promising in the biodegradation of alkanes and can also be utilized to clean up pollution from petroleum spill which is becoming a prevalent ecological hazard.
\end{abstract}

DOI: $\underline{\text { https://dx.doi.org/10.4314/jasem.v24i6.7 }}$

Copyright: Copyright (C) 2020 Adetitun et al. This is an open access article distributed under the Creative Commons Attribution License (CCL), which permits unrestricted use, distribution, and reproduction in any medium, provided the original work is properly cited.

Dates: Received: 14 October 2019; Revised: 16 May 2020; Accepted: 10 June 2020

Keywords: Air, Bacillus cereus, Biodegradation, Hospitals, Hydrocarbons

Different approaches can be used in the biodegradation of hydrocarbons (Adetitun, 2020). The atmosphere is composed of gases such as nitrogen, oxygen, carbon dioxide etc. In addition to these gases, air also contains dust particles, water vapor, and microorganisms. Air is not a natural environment for microorganisms because it lacks enough moisture and nutrients to support microbial growth and reproduction and as such, there are no indigenous microorganisms associated with air. Air is only a medium for the transport and dispersal of microorganisms. Microorganisms are transported from aquatic or terrestrial habitats most of which are attached to fragments of dried leaves, dust particles or are blown by the wind. Microorganisms require a number of environmental factors that make them thrive in any environment they are found. Moreover, some meteorological factors influence microbial population in air. These factors include: Nutrients, Temperature, Moisture, Light Intensity, Air current, Height at which the microorganisms are found etc (Chandra et al., 2005). Hence, microorganisms are found in relatively small numbers in air when compared to soil and water. Microorganisms in air can be grouped into indoor and outdoor air microflora. Numerous genera of fungi and bacteria are found in indoor air. Some of these include: Penicillium, Aspergillus, Staphylococcus, Bacillus, Clostridium etc. In addition, certain genera of bacteria are found in outdoor air and they are inclusive of but not restricted to: Bacillus, Clostridium, Sarcina, Micrococcus, Staphylococcus etc. Bacillus cereus is a toxinproducing facultative anaerobic, Gram positive bacteria found to be ubiquitous in nature. They are often found in soil and vegetation although; they have also been implicated in food poisonings (Nguyen and Tallent, 2019). Moreover, infectious diseases are also transmitted by bacteria and viruses which are dispersed in air by droplets of saliva and mucus produced by coughing, sneezing, talking etc. Anthropogenic activities such as ploughing, digging, sweeping among others release soil borne microbes into air and they can remain suspended for long periods of time. The splashing of water by wind and tidal actions also release microorganisms into the air in form of water droplets and aerosols. Air quality is thus a determining factor of the quality of human health (Tambekar et al., 2007). The rooms and wards of hospitals can be filled with dust housing infectious microorganisms such as Streptococcus, Pneumococcus, Staphylococcus etc that aid in the spread of nosocomial infections. According to Arzu et 
al. (2019), nosocomial infections are transmitted directly or indirectly through air. Exposure to bioaerosols, containing airborne microorganisms and their by-products, can result in respiratory disorders and other adverse health effects such as infections, hypersensitivity pneumonitis etc. Air is often exposed to sunlight making it have a higher temperature and less moisture. So, if not protected from desiccation, most of these microbial forms will die. Pollution from petroleum and its allied products is increasing at an alarming rate due to continuous growing demands (Xiumei et al., 2019) and this has attracted considerable attention owing to its harmful effect on the environment (Meng et al., 2016). Exploitation and production and transportation of massive amount of petroleum products results in frequent spillage (Deng et al., 2014). Hydrocarbons can be degraded by different indigenous microorganisms which are capable of breaking down particular hydrocarbon molecules. Among microorganisms associated with petroleum degradation are: Acinetobacter, Bacillus, Pseudomonas, Rhodococcus etc (Hassanshahian et al., 2014; Varjani, 2017).

This study aims to isolate, identify and characterize bacteria endospores from indoor and outdoor air of some hospitals in Ilorin, Kwara State and to also evaluate the ability of Bacillus cereus to degrade hydrocarbons.

\section{MATERIALS AND METHODS}

Sample Sites: The sample sites were five private hospitals in Ilorin, Kwara state.

Sample Collection: Air sampling was done at selected hospitals during working hours. Settling plate method was used where Petri dishes containing Nutrient agar were exposed to air for 10 minutes. Three plates were used for the indoor and outdoor sampling respectively. The plates were then taken to the laboratory and incubated at $37^{\circ} \mathrm{C}$ for 24-hour as described by Cheesebrough (2010).

Sample Bioassay: Preparation of media was carried out in accordance with the directions provided by the manufacturer. All media were sterilized in an autoclave at $121^{\circ} \mathrm{C}$ for 15 minutes. Also, glass wares were thoroughly washed and sterilized in the oven at $170^{\circ} \mathrm{C}$ for 1 hour before use. Pouring of media into plates as well as other microbiological processes was carried out aseptically (Fawole and Oso, 2004).

Preparation of nutrient agar: Nutrient agar used was prepared by dissolving 28 grams of nutrient agar powder in 1Litre of sterile distilled water and homogenized. It was then sterilized in the autoclave at $121^{\circ} \mathrm{C}$ for 15 minutes as described by Fawole and Oso (2004).

Preparation of Mineral Salts Medium (MSM): One litre of Mineral Salt Medium (MSM) was prepared and $25 \mathrm{ml}$ was aseptically poured into 36 reagent bottles. MSM is composed of $\left(0.5 \mathrm{~g} \mathrm{KH}_{2} \mathrm{PO}_{4}, 1.4 \mathrm{~g} \mathrm{Na}_{2} \mathrm{HPO}_{4}\right.$, $0.2 \mathrm{~g} \mathrm{MgSO}_{4} .7 \mathrm{H}_{2} \mathrm{O}, 0.3 \mathrm{~g} \mathrm{KNO}_{3}$ and $\left.1 \mathrm{~g}\left(\mathrm{NH}_{4}\right)_{2} \mathrm{SO}_{4}\right)$. This study involves biodegradation of hexadecane and Heptane. Measured hydrocarbons were added to the sterile MSM and each bottle was inoculated with $0.5 \mathrm{ml}$ of broth. For each concentration of hexadecane and heptane, the bottles were labeled A41 and A42. Three bottles (A41, A42 and control) were taken from the hydrocarbons with a 4 days interval over a period of 20 days. The absorbance at wavelength $600 \mathrm{~nm}$ was checked and recorded. After the first setup, another MSM was prepared for heptane and decane over a period of 5 days and absorbance checked daily.

Isolation and Characterization of Bacteria: After an incubation period of 24 hours, the plates were observed to comprise of different colonies. The different colonies in each culture were labeled as A1, A2, A3 to A15 respectively. Pure cultures of each bacterial colony were prepared by streaking unto sterile Nutrient agar plates in order to obtain discrete colonies. Identification and characterization of bacteria isolates was done morphologically and microscopically. Biochemical tests were also carried out.

Measurement of Biodegradation: A spectrophotometric procedure based on absorbance was developed to verify biodegradation of hexadecane and heptane. Analyses were carried out by taking the samples from the appropriate bottles for 20 days with a 4 - day interval after which the samples were assayed for bacterial growth using the Jenway 6320D spectrophotometer at a measurement of $600 \mathrm{~nm}$.

\section{RESULTS AND DISCUSSION}

A total of 15 bacteria isolates were obtained from this study. Growth were observed on plates exposed to air at Ola-Olu Hospital, Olotu Hospital and Civil Service Hospital while the plates exposed at Temitope Hospital and Ore-Ofe Hospital had no growth after 24hours. The plates were coded as: A1, A2, A3, A4, A5, A6, A7, A8, A9, A10, A11, A12, A13, A14, and A15. However, five of the isolates were found to be spore formers and they were found on plates: A1, A4, A7, A10 and A12. The isolate on plate A4 was identified as Bacillus cereus using biochemical tests. Table 1 describes the morphological characteristics of the isolates obtained in this research. The morphological characteristics obtained in Table 1 showed Bacillus cereus to be the probable isolate on 
plate A4. However, further biochemical tests conducted established the isolate A4 to be Bacillus cereus as shown on Table 2.

Table 1: Colonial morphology of bacteria isolates

\begin{tabular}{|c|c|c|c|c|c|c|c|}
\hline A1 & Irregular & Undulate & Raised & Rough & Opaque & Small & Cream \\
\hline A2 & Rhizoid & Entire & Flat & Rough & Opaque & Large & Cream \\
\hline A3 & Oval & Entire & Raised & Smooth & Opaque & Small & Cream \\
\hline A4 & Rhizoid & Undulate & Raised & Rough & Opaque & Medium & Cream \\
\hline A5 & Rhizoid & Undulate & Flat & Smooth & Opaque & Large & Cream \\
\hline A6 & Circular & Entire & Raised & Rough & Opaque & Small & Cream \\
\hline A7 & Circular & Entire & Flat & Rough & Opaque & Large & Cream \\
\hline A8 & Circular & Entire & Flat & Glistering & Opaque & Small & Yellow \\
\hline A9 & Circular & Entire & Flat & Glistering & Opaque & Small & Yellow \\
\hline A 10 & Irregular & Undulate & Flat & Round & Opaque & Large & Cream \\
\hline A11 & Rhizoid & Undulate & Flat & Smooth & Opaque & Small & Cream \\
\hline A12 & Rhizoid & Undulate & Raised & Rough & Opaque & Small & Cream \\
\hline A13 & Circular & Entire & Raised & Rough & Opaque & Small & Cream \\
\hline A14 & Circular & Entire & Flat & Rough & Opaque & Small & Cream \\
\hline A15 & Rhizoid & Undulate & Flat & Glistering & Opaque & Small & Yellow \\
\hline
\end{tabular}

Table 2: Biochemical tests on Bacillus cereus

\begin{tabular}{lccccccccc}
\hline \multicolumn{10}{c}{ Biochemical Tests } \\
\hline Gram & Catalase & Coagulase & Oxidase & Vogas- & Methyl & Indole & Starch & Hemolysis & Spore Stain \\
Stain & & & & & Proskauer & Red & & hydrolysis & \\
+ & + & + & - & + & - & - & + & + & + \\
\hline
\end{tabular}

Legend: + = Positive; - = Negative

An initial experimental set- up for absorbance was measured for 20 days using a Jenway 6320D spectrophotometer to check the growth configuration of Bacillus cereus. The growth curve for hexadecane and heptane are depicted in Figures 1 and 2 respectively.

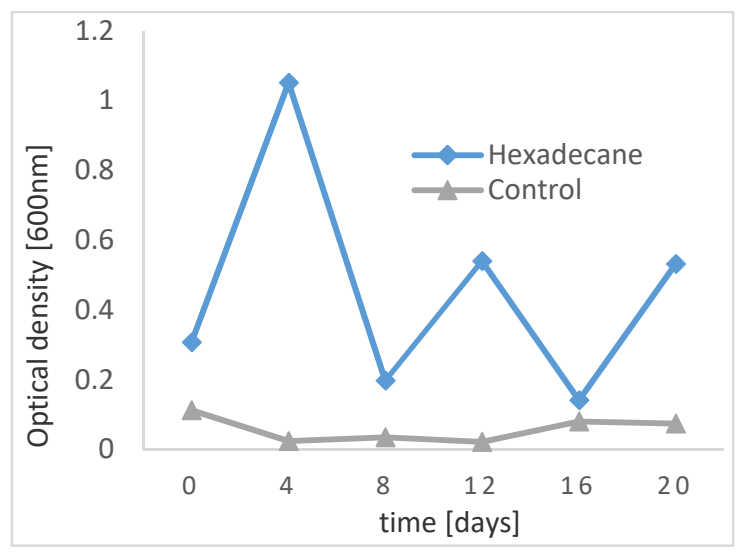

Fig 1: Growth configuration of Bacillus cereus on hexadecane.

The result obtained for hexadecane in figure 1 shows intermittent fluctuations in hydrocarbon degradation by Bacillus cereus. A sharp increase was observed on Day 4 and Day 20 with optical readings of $1.051 \mathrm{~nm}$ and $0.532 \mathrm{~nm}$ respectively. However, there followed a decrease in optical density on Day 8 and Day 16 with optical readings of $0.198 \mathrm{~nm}$ and $0.141 \mathrm{~nm}$ respectively. Effective biodegradation is dependent on optimal biological (microbial functionality and biomass size), chemical (bioavailability and nutrients) and physical (water holding capacity) parameters
(Towell et al., 2011). The growth configuration of Bacillus cereus on heptane as described in figure 2 shows an optical density of $0.82 \mathrm{~nm}$ on Day 4 which serves as the highest degradation value; Day 8 to Day16 witnessed a decline in degradation and then a jerk in growth was experienced on Day 20 which had a reading $0 \mathrm{f} 0.37 \mathrm{~nm}$. It can be deduced that the isolate was able to utilize the available nutrients hence its efficient degradation of the hydrocarbon on Day 4. The sudden increase by Day 20 may be due to the proliferation of the microbial cells and production of various intermediate metabolites (Towell et al., 2011). To measure the rate of increase till Day 4, a second experiment was setup with decane and heptane and optical density measured daily for a period of 5days as seen in figures 3 and 4 respectively.

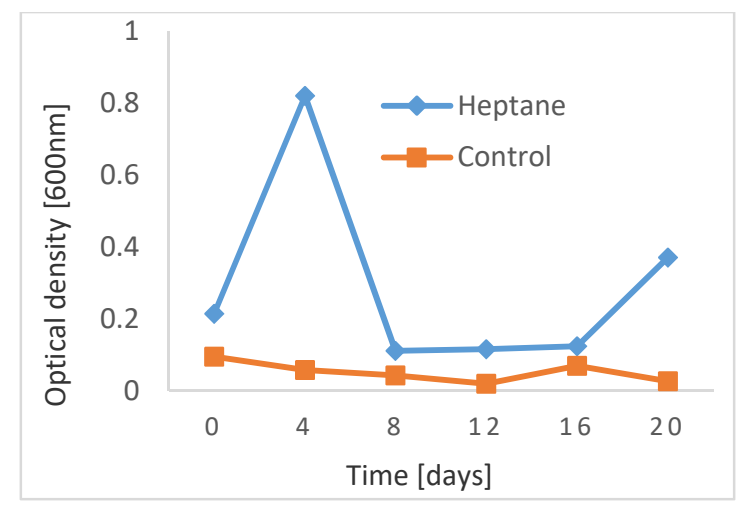

Fig 2: Growth configuration of Bacillus cereus on heptane

Similar results were also gotten in the second experimental set-up as Bacillus cereus utilized the 
hydrocarbons till the fourth day. Figure 3 gave increased optical readings from day 1 to day 4 in decane degradation with the highest value recorded as $0.431 \mathrm{~nm}$ on day 4 and the lowest value of $0.338 \mathrm{~nm}$ recorded on day 5. Also, figure 4 depicts an increase in heptane degradation with day 4 having the highest value of $0.451 \mathrm{~nm}$ and a decline in degradation was further noted on day 5 with an optical reading of $0.343 \mathrm{~nm}$.

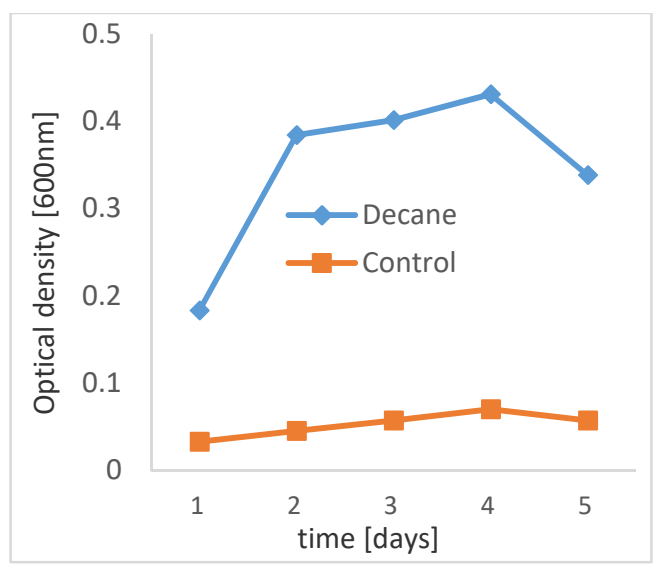

Fig 3: Growth configuration of Bacillus cereus on Decane

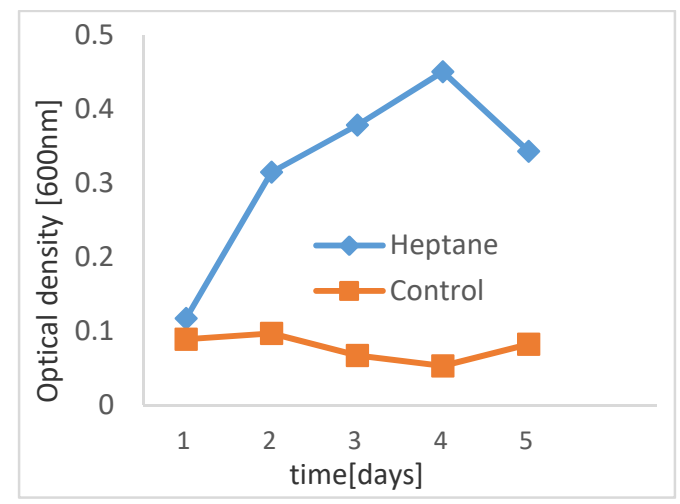

Fig 4: Growth configuration of Bacillus cereus on Heptane

Production of extracellular enzymes by microorganisms play an important role in hydrocarbon degradation because molecules are broken down into smaller subunits then further degraded into intermediary products that can be assimilated into microbial cells and utilized as carbon sources leading to production of energy, water, carbon dioxide, and methane in the case of anaerobic respiration (Brown and Chang, 2014; Müller, 2005). Also the bioavailability of hydrocarbons which is largely a function of concentration and physical state, hydrophobic nature, volatilization and solubility of hydrocarbons greatly affects the extent of biodegradation (Chandra and Chowdhary, 2015). Many microorganisms especially bacteria are producers of enzymes such as peroxidases and laccases that are capable of degrading petroleum hydrocarbons (Falade et al., 2017). They have also been found to play important roles in carbon cycling (Bugg and Rahmanpour, 2015).

According to Ghoreishi et al. (2017) and Zanaroli et al. (2010), the outcome of using suitable microorganisms in the degradation of petroleum hydrocarbons is the breakdown of toxins to non-toxic compounds. The study of Xiumei et al. (2019) reported that single bacterial strains were inefficient for bioremediation and this was supported by (Ghorbannezhad et al., 2018; Khan et al., 2018) who stated that a consortium of bacterial strains are able to degrade petroleum hydrocarbons at higher rates than single bacterial strains. This claims are true as petroleum consists of thousands of hydrocarbons. However, the hydrocarbon degrading ability of Alcaligenes sp. strain $3 \mathrm{k}$ was demonstrated by Adetitun et al. (2019) and the organism was found to be a good degrader of aromatic hydrocarbons and lignin. Furthermore, Bacillus cereus has been found to be a good bioremediation candidate in the biodegradation of hydrocarbons due to its ability to produce enzymes laccase and manganese peroxidase (Forootanfar and Faramarzi, 2015). Bacteria laccases are implicated in various processes ranging from UV protection, pigmentation, metal oxidation, sporulation to xenobiotic degradation. Due to the widespread existence and versatility of bacteria, bacteria laccases have higher thermostability, alkaline $\mathrm{pH}$, and halotolerance. The ability of laccases to effectively degrade a variety of persistent organic pollutants (POPs) has received considerable attention in the field of bioremediation (Gasser et al., 2014).

Conclusion: This study proves that Bacillus cereus has biodegradation potentials and it can be used for the large-scale biodegradation of spills from petrochemical hydrocarbons. Thus, microbial mediated biodegradation of environmental pollutants is a promising technique to clean-up contaminants.

\section{REFERENCES}

Adetitun, DO (2020). Different approaches to the Biodegradation of Hydrocarbons in halophilic and Non-halophilic Environments. In: Current Microbiological Research in Africa, Selected Applications for Sustainable Environmental Management. Editors: Akebe Luther King Abia \& Guy R. Lanza. Published by Springer Nature Switzerland. ISBN: 978-3-030-35295-0.

Adetitun, DO; Fathepure, B; Hugh, H; Kolawole, OM; Olayemi, AB (2019). Degradation of hydrocarbons 
and lignin-like compounds by Alcaligenes sp. strain 3k isolated from Ilorin. Poll. 5(2):269-277.

Arzu, K; Samyukta, T; Shyaron, P; Sony, S; Pramila, P (2019). Bacteriological assessment of the indoor air of different hospitals of Kathmandu District. Inter $J$ of Micro. 5320807:1-9.

Brown, ME; Chang, Mc (2014). Exploring bacterial lignin degradation. Cur Opin in Chem Biol. 19:1-7.

Bugg, TD; Rahmanpour, R (2015). Enzymatic conversion of lignin into renewable chemicals. Cur Opin in Chem Biol. 29: 10-17.

Chandra, PM; Venkata, SM; Reddy, SJ (2005). Microbiological method for monitoring the environment, water and waste. Academic Press, London.

Chandra, R; Chowdhary, P (2015). Properties of bacterial laccases and their application in bioremediation of industrial wastes. Env Sc: Proc and Imp. 17,326342.

Cheesebrough, M (2010). District laboratory practice in tropical countries, 3rd edition. Cambridge University Press, India.

Deng, MC; Li, J; Liang, FR; Yi, M; Xu., XM; Yuan, JP; Peng, J; Wu, CF; Wang, JH (2014). Isolation and characterization of a novel hydrocarbon degrading bacterium Achromobacter sp. HZ01 from the crude oil contaminated seawater at the Daya Bay, Southern China. Mar Poll Bull. 83(1):79-86.

Falade, AO; Nwodo, UU; Iweriebor, BC; Green, E; Mabinya, LV; Okoh, AI (2017). Lignin peroxidase functionalities and prospective applications. Micro Open. 6(1): 394.

Fawole, MO; Oso, BA (2007). Laboratory manual of microbiology, Spectrum Books Limited, Ibadan, Nigeria.

Forootanfar, H; Faramarzi, MA (2015). Insights into laccase producing organisms, fermentation states, purification strategies, and biotechnological applications. Biotech Prog. 31:1443-1463.

Gasser, CA; Ammann, EM; Shahgaldian, P; Corvini, PF (2014). Laccases to take on the challenge of emerging organic contaminants in wastewater. Appl. Micro. Biotech. 98: 9931-9952.

Ghorbannezhad, H; Moghimi, H; Dastgheib, SMM (2018). Evaluation of heavy petroleum degradation using bacterial-fungal mixed cultures. Ecotox and Env Saf. 164:434-439.
Ghoreishi, G; Alemzadeh, A; Mojarrad, M; Djavaheri, M (2017). Bioremediation capability and characterization of bacteria isolated from petroleum contaminated soils in Iran. Sust. Environ. Res. 27(4): 195-202.

Hassanshahian, M; Emtiazi, G; Caruso, G; Capello, S (2014). Bioremediation trials of oil polluted seawater: A mesocosm stimulation study. Mar Environ. Res. 95:28-38.

Khan, MAI; Biswas, B; Smith, E; Naidu, R; Megharaj, M (2018). Toxicity assessment of fresh and weathered petroleum hydrocarbons in contaminated soil. A Review: Chem. 212: 755-767.

Meng, L; Liu, H; Bao, M; Sun, P (2016). Microbial community structure shifts are associated with temperature, dispersants and nutrients in crude oilcontaminated seawaters. Mar Poll Bull. 111(1-2): 203-212.

Müller, RJ (2005). Biodegradability of polymers: Regulations and methods for testing. Biopol. 4: 365374.

Nguyen, AT; Tallent, SM (2019). Screening food for Bacillus cereus toxins using whole genome sequencing. Food Micro. 78:164-170.

Tambekar, DH; Gulhane, PB; Bhokare, DD (2007). Studies on environmental monitoring of microbial air flora in the hospitals. J of Med Sc. 7:67-73.

Towell, MG; Bellarby, J; Paton, GI; Simon, CF; Pollard, JT; Semple, KT (2011). Mineralization of target hydrocarbons in three contaminated soils from former refinery facilities. Environ. Poll. 159:515523.

Varjani, SJ (2017). Microbial degradation of petroleum hydrocarbons. Biores. Tech., 223:277-286.

Xiumei, T; Xiaoli, W; Shitao, P; Zhi, W; Ran, Z; He, T (2019). Isolation, screening and crude oil degradation characteristics of hydrocarbons degrading bacteria for treatment of oily wastewater. Water Sci. Tech. 78(12):2626-2638.

Zanaroli, G; Toro, SD; Todaro, D; Varese, GC; Bertolotto, A; Fava, F (2010). Characterization of two diesel fuel degrading microbial consortia enriched from a non-acclimated, complex source of microorganisms. Micro Cell Fact. 9(10): 1-13 